\title{
The Impact of Using Digital Technology Applications on the Egyptian Museum's Display
}

\author{
Rania Mostafa Eshaq Abdalla, Ali Omar Abdallah and Osama Abd El-Wareth Abd El-Megiud
}

\begin{abstract}
Using digital technology in museums could bridge gaps between museums and their audiences. Different types of applications could be helpful for the visitors if used in the right place, at the right timing, and in line with the right needs to be an increasingly core element of museums' strategy. The challenge for museums is to meet their visitors where they are, focusing on how they can leverage the right technology tools that best support their mission. A well-trained staff assisted by digital technology is essential as technology become an important element to enhance the museum's experience. The main purpose of the study is to explore the extent to which using technology in the Egyptian museum's display could influence the effectiveness of the museum in targeting new market segments of the Egyptian community meeting their current needs and interests. Since technology could improve the current museum's display shedding light on unknown information beyond the invaluable artifacts and presenting new experiences to the Egyptian visitor. Egyptian museums should identify how to convey information to the audience without any complications with the aid of effective techniques focusing on the challenges of using such kinds of applications in museums of Egypt. Some applications could be considered one of the main methods of visitor interpretation that has a deep impact on the current museum's display.
\end{abstract}

\section{Keywords:}

Museums, display, interpretation, ICT technology

\section{Introduction}

Nowadays, Information and Communication Technology (ICT) which are fully present in all fields are considered one of the innovative methods to develop any field. This paper aims to investigate the impact of using ICT in museums. The investigation includes both the museum's displaying methods, and visitor's impressions about applying technology applications on the artifacts. This paper will focus on the Egyptian museums where there is neither a significant nor an efficient usage of such technologies. It has been observed that there were some previous attempts in the form of experimental technical projects in the Egyptian museum such as the audio guide and the touch screen. However, these attempts were not completed, and were running timidly between supporters and opponents.

Thus, it was necessary to explore the impact of applying technological applications on museums' display and propose suggestions for the means of applying such applications to the Egyptian museums. Technology must balance between the nature of the exhibits, and methods of display, taking into consideration the main context of this display and the requirements of the artifacts. The study concluded that the current traditional displaying methods used in Egyptian museums are not efficient enough in interpreting many of the displayed artifacts.

Accordingly, it is proposed to use technology in the Egyptian museums to enhance the role of these museums in spreading cultural heritage, attracting more visitors to museums, and helping professionals to discover and reveal more secrets of the past. The current interpretation of the display of the Egyptian museum is not enough to convey the information to the visitors. This paper aims to investigate the impact of applying technology applications on museums' experiences in general, and the Egyptian museums in particular, where there is no interest in using these kinds of technologies in the permanent display. The first phase of the study encompasses the data collection process through both quantitative and qualitative research methods as follows:

1. Interviews and direct communications, such as face-to-face discussions and brainstorming, field research and phone conversations with specialists in museology, display and design to record their views on the current status of display at the Egyptian Museum.

2. Various surveys to record the views of Egyptian Museum's curators and visitors (children, teenagers, adults and seniors) to note the impact of existing display on visitors. This aims to investigate the opinions of various groups of audience on how to improve the display and make it informative and enjoyable.

The second phase includes the data analysis process (See page 6-12). 


\section{Technology Investigation}

There are many artifacts in museums that the whole world seeks to explore the story beyond. Unfortunately, those objects stand in their places without telling their story or revealing their secrets. Therefore, Egyptian museums need to attract the public specially local visitors; for achieving this target, they should provide interactive services for meeting their needs to avoid visitor's moving from one gallery to another, and from an object to another just reading their information from the labels which don't introduce the whole meaning of it.' The way individuals spend their leisure time in museums needs effective modern techniques to facilitate the information to the public, and this is one of the purposes of a museum. Modern techniques help the public to
engage in social fields, and to participate in museums. ${ }^{2}$ Nowadays, smart-phones, and wireless internet exist everywhere; $\mathrm{Wi}$-Fi became essential for mobiles (See figure 1). Unfortunately, as the Egyptian museums have no $\mathrm{Wi}_{\text {i-Fi; }}$; visitors cannot gain access
bestin to applications that supply background information about the object. To integrate technology into the museum building, tools and devices should be at a reasonable price with low maintenance requirements.

\section{The Egyptian Museum in Cairo}

The Egyptian museum is one of the most important museums for ancient Egyptian artifacts; it still keeps its ancient identity as a place for preserving artifacts. The first display of the museum's collection was considered an outstanding display compared with other museums at the same time; the same concept of the old display still exists till today. The objects on the ground floor are arranged in a chronological order, while on the first floor, they are classified by category or in collections; this is the time for change, and the permanent display of the Egyptian museum has to develop following the development of the scientific research field of the ancient Egyptian archaeology that was produced copiously through the recent years.

\section{Temporary projects by the CultNat (Center for documentation of Cultural and} natural Heritage) in the Egyptian Museum:

1. Culturama: It is a large panoramic display that surrounds the audience in 180 degrees. It is a semi-circle, which is 11 meters in diameter (See figure 2). However, it can be customized to have different forms. In addition, there is a vast area with a computer screen. This area is used for delivering a wide range of information that could have never been delivered using the display of a standard computer. This innovative project was registered sole right preserved for Egypt. Mini- Culturama (three screens), was used in the Exhibition of "One god and Three religions" in the Egyptian museum ${ }^{4}$ (See figure 3).

2. Hologram: It is an informative device or a media outlet; holograms responding to the low-voltage lighting that can be switched off to be transparent and invisible, and to allow another image to be seen beyond (See figure 4). Holograms can be produced digitally on television screen. Nowadays, it can also be mobile and computer-generated while it used to be static. Hologram is a clear three-dimension image contained in a flat plane. It was made in its original form by splitting a pure beam of laser light from a single source to give both a front and an angled view of the object at the same time; as a result, it is creating the depth impression.

Example: the hologram of the Mask of Tutankhamen (See figure 5) in the Egyptian museum that was used when the mask was under restoration, and the Hologram had an alternative role of the mask.

\section{Virtual Reality (VR):}

"VR is a cognitive environment, created by computational technology, which operates through the interactive simulation of

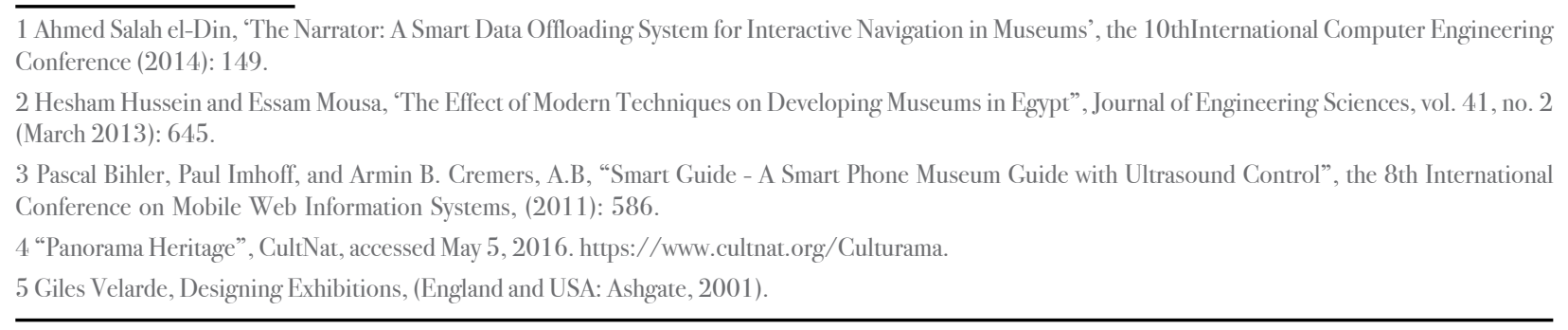

some aspects of reality (mainly iconic and auditory), in order to obtain knowledge, communicate or create art works." VR take different shapes such as Immersive Virtual Reality, Augmented Reality, and Hybrid Reality. It is supporting multimedia form of
communication that is dynamic and interactive. ${ }^{6}$.

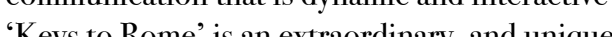

Whsthe explore the 'Culture of the Romans' which is called 'the serious game'; it starts with the city of Augustus to the whole Roman Empire, four museums with their archaeological objects participating in this exhibition, and more than 10 different types of technologies supporting, an

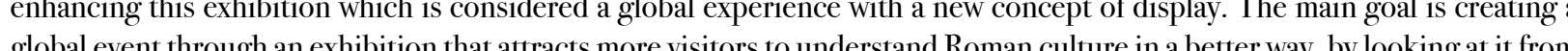
differ the first international exhibition which has been held in four locations at the same time as follows:

- Rome, in the Imperial Fora Museum (Museo dei Forilmperiali).

- Alexandria, in the Antiquities Museums of the Bibliotheca Alexandrin

- Amsterdam, in the Allard Pierson Museum.

- Sarajevo, in the City Hall (Vijecnica) and in the Museum of Sarajevo. ${ }^{7}$

The serious Game is a Virtual reality with natural interaction; it presents information according to its educational goal, in addition to more entertainment as a game by technology. It was performed in the children museum at the Egyptian Museum in Cairo and in Archeological Antiquities Museum at Bibliotheca of Alexandria (See figure 6). The game was performed two year ago by the CultNat; it was a natural interactive game, and very attractive for both children and adults. The participants of the children museum interated expectively with the game, some or them tried to explore the caste in the game, and discover every part with joy, and fun. Using interactive games as a way of museum display is one of the most effective educational tools if used wisely. ${ }^{8}$

\section{Selim Hassan Temporary Exhibition (November 2016)}

This exhibition was a cooperation between the Egyptian museum and the Alexandria library with the CultNat. This exhibition is considered as an example for using technology apps in temporary exhibitions such as: the Hologram (See figure 8) and the Cave-Virtual reality for the discovery of the Causeway of Unas-(See figure 9).

Selim Hassan - Legend of Egyptology - was the first Egyptologist in Egypt; the exhibition presented (included) the document of his excavations which were hand-written, and some objects of his excavations in Giza and Saqqara.

\section{Touch screen/Egyptian museum'sinteractive plan}

At the same time of Selim Hassan Exhibition opening, touch screen (EMC plan) and wall of knowledge of Tutankhamen, permanent display and mobile application, are introduced for the first time in the Egyptian Museum. The touch screen (Se figure 10) was displayed on the occasion of celebrating the $114^{\text {th }}$ anniversary of the opening of the Egyptian Museum.

\section{Wall of knowledge/ Tutankhamen's tomb discovery (See figure 11)}

'On the wall of knowledge, several subjects can be displayed. Here, the subject of "antechamber of the tomb of King Tutankhamen" has been chosen at the time of its discovery. Using "Augmented Reality", one can point a smart phone or tablet at many objects in the scene to view them in $3 \mathrm{D}$ and get more information about them. So, the visitor can get into the experience and enjoy it'. ${ }^{9}$

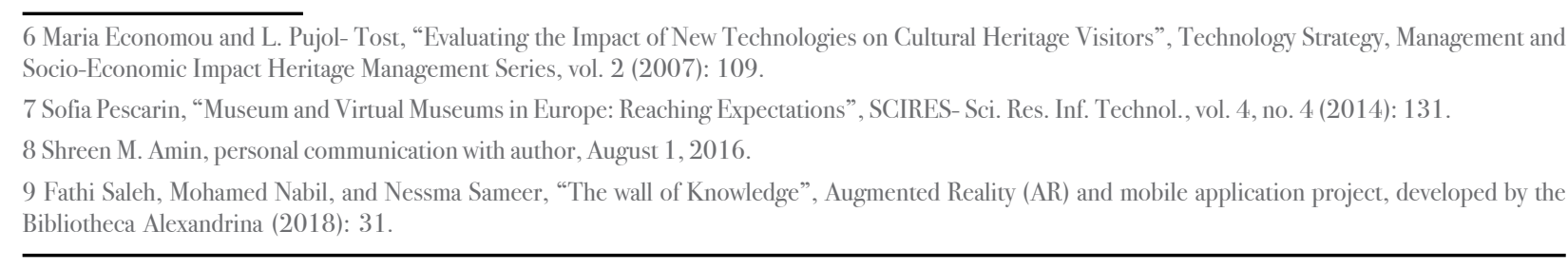




\section{Nile museum in Aswan, Egypt}

The contents of the Nile museum start with ancient Egyptians, and how they sanctified the Nile till the modern era, and what the Egyptian people did for preserving the Nile water in the development era. The reason for the reconstruction of the museum is reconnecting Egypt and the other African countries, exchanging knowledge and experiences since the new generations do not for spreading that basin countries are, and they do not know the source of the Nile; this is the main role of the Nile museum for spreading that information among youth. The monument decorating the entrance of the museum as a welcoming piece for
visitors is considered a call for peace; it contains all the eleven countries of the Nile basin including Egypt (See figure 12). The whole area is about 35 acres (See figure 13); the museum building occupies about 15 acres, and the other 20 acres will be the invested area, and this is an upcoming project by the Ministry of Housing to offer job opportunities, and cover the financial needs of the museum. The scenario of the Nile museum had a plan for using technology applications from the first moment needs of the museum. The scenario of the Nile museum had a plan for using technology applications from the first moment
including all types of applications that are now used. The museum did a survey on their visitors from the moment of opening on January $10^{\text {th }} 2016$ till Mav 2016 , based on the entry tickets; the total number of visitors was 157517 (See figure 14). ${ }^{10}$

\section{Digital Technology in thezNile museum in Aswan}

1. Digital boxes (showcases): it uses the computing system where the artifact is shown with its interpretation in the form of a short movie displaying around the object on that computing system (See figure15).

\section{Holograms (Holographic display):}

a. Pyramid holograms: it uses the reflective image of the artifact (See figure 16).

b. Digital Holograms: it uses the projection system. It is an informative device or a media outlet which is responding to the low-voltage lighting that can be switched off to be transparent and invisible, and to allow another image to be seen beyond (See figure 17).

\section{The Children's Civilization and Creativity Center}

This museum was opened in 1996 as 'Susan Mubarak museum for children in collaboration with the 'Natural history museum in UK. The board of the museum thought to modify the museum concept of display to be more interactive, in accordance with the children education currently. Thus, they decided to renovate the whole building under the supervision of the Armed forces. The Children's Civilization and Creativity Center in Heliopolis was opened in 2012, on 4,000 meters square with 14.3 acres landscape surrounding it (See figure 18). It was built for all the children of Egypt by the Heliopolis Society. The museum was designed by experts from Egypt, UK, and the USA. There were many contributions by specialists from international museums, and institutions all over the world to assist children, and young adults to learn through the new approach of interactivity by hands on exhibits, and computer games. A magnificent dome takes the visitor through the history of science in Egypt. The museum won the UK's Museum and Heritage International Award in May 2012. Children museums in general are based on educational purposes that have been clarified through interactive technologies; those museums have a different concept and context of display and the positive impacts versus the negative impacts is higher."

\section{Examples of the used technology}

1. Mummification and Medicine exhibition (See figure 19).

2. The Hologram of Tutankhamen tomb discovery (See figure 20 ).

3. Interactive touch screen-Hide and seek with fishes (See figure 21).

\section{Methodology}

A comprehensive methodology for developing museums in Egypt was proposed through questionnaire surveys with Egyptian museum's curators and visitors, interviews with intentionally chosen consulting offices specialized in museums displays, and specialists in the fields of museums, and technology.

The interviews were designed to figure out the real impact of using technology on the Egyptian museum's display. The interviews were conducted with:

- The director of the Children Museum for Civilization and Creativity, who is responsible for the display of the Nile museum, and the vice president of ICOM Arab; on the $7^{\text {th }}$ of May, 2016.

- The head of museums sector, Ministry of Antiquities; on the $25^{\text {th }}$ of May 2016.

- The Engineer at CultNat since it is documenting Egyptian heritage with technology; on the $18^{\text {th }}$ of July, 2016.

- The director of museums permanent display department, Museums sector, Ministry of Antiquities; on the $29^{\text {th }}$ of May 2016 - The General Director of the 'Cultural Development, Museum Education and Archeological Awareness' administration

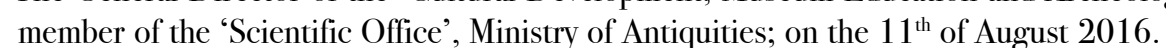

- The Museum educator in the 'Education and Culture Development' department at the 'National Museum of Egyptian Civilization' (NMEC), and student in Master of museum studies; on the 10 $10^{\text {th }}$ of April, 2016.

\section{The analyses of the interviews}

Based on the interviews with the various entities in museums, and technology specialists the evaluation has been divided to three main levels that indicate the impact of using technology in the Egyptian museums. The first one is a positive impact, the second is a moderate impact, and finally, the third level is the nerative impact of using technology. The total impressions indicated the digital technology is:

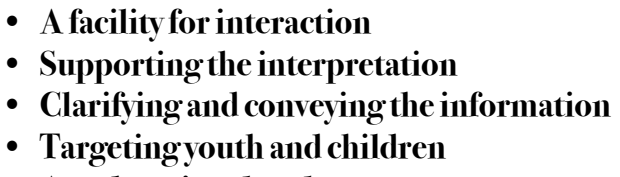

Questionnaires had been done with the curators of the Egyptian museum, including different questions to evaluate the appreciation of using technology in the museum display.

Based on the questionnaires with the curators of the Egyptian museum, and according to the different kinds of questions, the evaluation has been divided to three main answers that indicated the feedback of each one of them regarding using technology in the Egyptian museums. The first answer is (Agree), the second answer is (Disagree), and finally, the third one is (No answer) the total answers in (table 1):

\section{Table 1: Evaluation of the Egyptian museum curators}

\begin{tabular}{|c|l|c|c|c|}
\hline \multicolumn{5}{|c|}{ Egyptian museum curators } \\
\hline \multicolumn{1}{|c|}{ Questions } & Agree & Disagree & No answer \\
\hline 1 & Are you satisfied with the methods of display? & 1 & 14 & 0 \\
\hline 2 & $\begin{array}{l}\text { In your opinion, are there any disadvantages in the } \\
\text { way of display? }\end{array}$ & 15 & 0 & 0 \\
\hline 3 & $\begin{array}{l}\text { Do you have any suggestions for developing the } \\
\text { display? }\end{array}$ & 12 & 2 & 1 \\
\hline 4 & $\begin{array}{l}\text { Do Technology applications in a display convey the } \\
\text { information easier to the visitors? }\end{array}$ & 15 & 0 & 0 \\
\hline
\end{tabular}




\begin{tabular}{|c|l|c|c|}
\hline 5 & $\begin{array}{l}\text { In your opinion, what are the advantages and } \\
\text { disadvantages of using technology applications as an } \\
\text { interpretation means in a museum display? }\end{array}$ & Answer & No answer \\
\cline { 3 - 4 } & & 13 & 2 \\
\hline
\end{tabular}

The statistics for each question separately

The first question was, 'Are you satisfied with the methods of display?'; this question was designed to evaluate the current approach of managing the display of the Egyptian museum from an archaeological point of view (Chart 1).

- $7 \%$ Agree.

- $93 \%$ Disagree.

\section{Chart 1 : The result of the first question}

The second question was, 'in your opinion, are there any disadvantages in the way of the display? It was designed to evaluate the most negative points in the Egyptian museum display, and the percentage of curator's satisfaction (Chart 2).

- $100 \%$ Agree

\section{Chart 2: The result of the second question}

The third question was, 'Do you have any suggestions for developing the display? It was designed to evaluate the percentage of the awareness of the importance of the museum display itself (Chart 3).

- $80 \%$ Agree.

- 73 \% Disagree.

- $7 \%$ no answer.

\section{Chart 3: The result of the third question}

The fourth question was, 'Do technology applications in a display convey the information easier to the visitors? It was designed to evaluate the appreciation of the curators of using the technology in the museum display (Chart 4).

- $100 \%$ Agree.

- $0 \%$ Disagree

\section{Chart 4: The result of the fourth question}

The fifth question was, 'In your opinion, what are the advantages and disadvantages of using technology applications as an interpretation mean in a museum display? It was designed to evaluate their current knowledge of technology (Chart 5).

- $87 \%$ Agree.

- $13 \%$ no answer.

\section{Chart 5: The result of the fifth question}

The analyses of the questionnaires of the Egyptian museum curators

Curators welcome and approve on using technology in the museum display. They are a bit reticent, as archaeologists they don't want the objects to lose their values, but at the end they are eager to catch up with the technology race and stay tuned with it The majority of the Egyptian community has no appreciation or understanding of the importance of technology applications used in Egyptian Museums. In order to evaluate community appreciation, questionnaires were used with different questions to assess the real appreciation. $\quad$ a different Based on the questionnaires with the community visitors of the Egyptian museum in Cairo, and according to the different kinds of questions, the evaluation has been divided to three main answers that indicated the feedback of each one about using technology in these museums, the first answer was (Yes), the second answer was (No), and finally, the third one was (No answer); the total answers in (table 3):

\section{Table 2: Evaluation of the Egyptian museum visitors}

\begin{tabular}{|l|l|l|l|l|}
\hline \multirow{2}{*}{ Questions Agree } & \multicolumn{3}{|l|}{ Egyptian museum community visitors } \\
\cline { 2 - 5 } & Disagree & No answer & \\
\hline 1 & Did you visit the Egyptian/ Nile museum before? & 11 & 4 & 0 \\
\hline 2 & Are you satisfied with the methods of display? & 9 & 6 & 0 \\
\hline 3 & $\begin{array}{l}\text { In your opinion, are there any disadvantages in the way } \\
\text { of the display? }\end{array}$ & 11 & 4 & 0 \\
\hline 4 & Do you have any suggestions for developing the display? & 6 & 8 & 1 \\
\hline 5 & $\begin{array}{l}\text { Do Technology applications in a display convey the } \\
\text { information easier to the visitors? }\end{array}$ & 12 & 2 & 1 \\
\hline 6 & $\begin{array}{l}\text { In your opinion, what are the advantages and } \\
\text { disadvantages of using technology applications as an } \\
\text { interpretation mean in a museum display? }\end{array}$ & Answer & & No answer \\
\cline { 5 - 5 } & & 8 & 8 \\
\hline
\end{tabular}

The statistics for each question separately

The first question was, 'Did you visit the Egyptian museum before?

This question was used to evaluate the real marketing approach of the Egyptian museum in Cairo which does not use technology in display (Chart 6).

- 73\% Agree.

\section{Chart 6: The result of the first question}

The second question was, 'Are you satisfied with the methods of display?' this question was used to evaluate the current approach of managing the display of the Egyptian museum (Chart 7).

- $40 \%$ Disagree.

\section{Chart 7: The result of the second question}

The third question was, 'In your opinion, are there any disadvantages in the way of the display? This question was used to evaluate the negative points in the Egyptian museum display, and the percentage of visitors' satisfaction (Chart 8). - $73 \%$ Agree.

- $27 \%$ Disagre

\section{Chart 8: The result of the third question}

The fourth question was, 'Do you have any suggestions for developing the display? This question was used to evaluate the percentage of awareness of the Egyptian community to the use of technology in the museum display, and its importance (Char 9).

- $40 \%$ Agree.

- $53 \%$ Disagree

- $0 \%$ no answer 


\section{Chart 9: The result of the fourth question}

\section{The fifth question was:}

Do technology applications in a display convey the information easier to the visitors? This question was used to evaluate the awareness of using technology in the Egyptian community (Chart 10).

- $80 \%$ Agree.

- $0 \%$ no answer.

\section{Chart 10: The result of the fifth question}

The sixth question was, in your opinion, what are the advantages and disadvantages of using technology applications as an interpretaion mean in a museum display? This question was used to evaluate the current knowledge of technology (Chart 11). - $47 \%$ Agree.

\section{Chart 11: The result of the sixth question}

\section{The analyses of the questionnaires of the Egyptian Museum community visitors}

- Most of the visitors did not understand the meaning of display through technology, and they do not know any of the applications of technology that might be used in the museum display. For that reason most of them did not answer question six which is: 'in your opinion, what are the advantages and disadvantages of using technology applications as an interpretation means in a museum display??

- The majority of visitors visited the Egyptian museum only once before with their schools

- The majority of visitors agreed on using technology in museums, although they don't know how to use it, they do not have any knowledge of using technology devices, they just need to keep up with development.

- They did not like the display of the Egyptian museum, although the majority of them do not know what the meaning of display is, they just comment on lighting systems, interpretation, and the visit route as a disadvantage of museum display.

\section{Recommendations}

- Based on the answers of the questionnaires that were done by curators of the Egyptian museum and its local visitors, two main aspects have been recommended. First, the Egyptian museum has to develop its display. Second, the museum

Using digital technology in Egyptian museums will enhance the role of museums in spreading cultural heritage and attract more visitors.

- The Egyptian Museums should take into account that young people want technology and thus try to satisfy them, but also consider the elder people who do not appreciate using digital technology, especially in archaeological museums.

\section{Conclusion}

Application of digital technologies in museums would have been much easier and more effective if applied in the right place, at the right timing and in line with the right needs. It is also essential to have the well-trained staff assisted by digital technology framework and strategic planning. Technology is the application of knowledge for practical ends, allowing creation and the use of technical means on various sciences in different places, such as museums. Based on the findings of previous investigations on technologies already in use in museums, the evaluation of the impact of such usage is definitely positive.

The analyses of using technologies in exhibits have proved that the Egyptian authorities, alongside general visitors and local communities, desire technology. The role played by the Eoyptian museums is to meet their needs and to cater for the variance of mentalities. Egyptian museums have to regain their main audience and to target new categories of visitors through improving the current exhibit arrangements with the aid of effective techniques to convey information to such audience without any complications. As a matter of fact, these techniques are essential to satisfy the desires of visitors.

To achieve such goals, it is vital to monitor the technology trend in the market and implore the latest ICT developments to attain thorough understanding of evolving technologies. In addition, it is important to identify innovative solutions and to apply new technology to existing products and services parallel to searching for sustainable alternatives and solutions for adaptation to current facilities.

Implementing technological products or services has to avoid any shortcomings or deficiencies in display methods such as inaccurate or insufficient written interpretation which should be clear and easily appreciated by the visitors to provide details for a complete understanding. The consequence of such mishaps will lead to the loss of their values as museums. Visions of our museums will be blurred or misinterpreted if technology is introduced without specifications. Despite the analyses confirming that the majority of the visitors agreed on using technology in museums, archaeologists dealing with invaluable artifacts in Egyp and all over the world have their doubts about the effects of such applications on the artifacts. It is still suspicious that suc application may pose negative consequences on the artifiacts on display. 
(1)

Figures

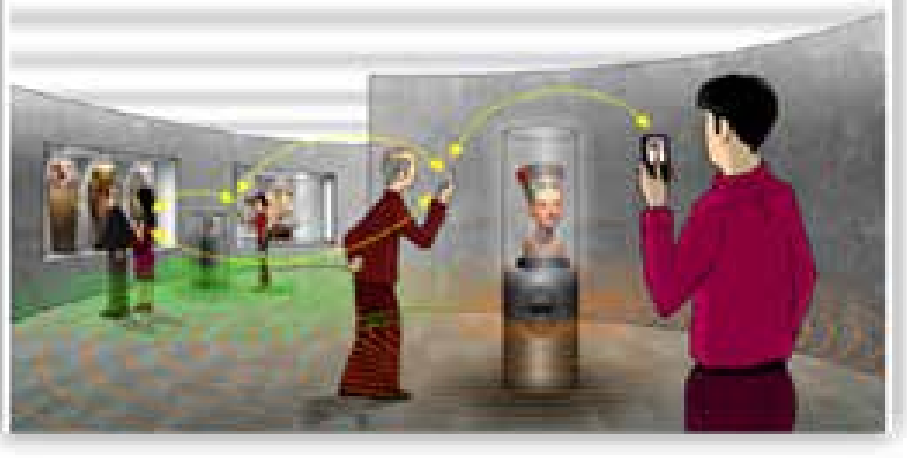

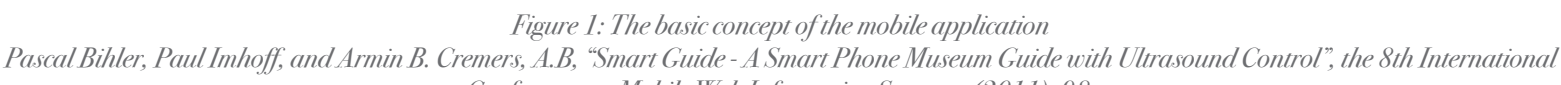
conference on Mobile Web Information Systems. (2011) 98

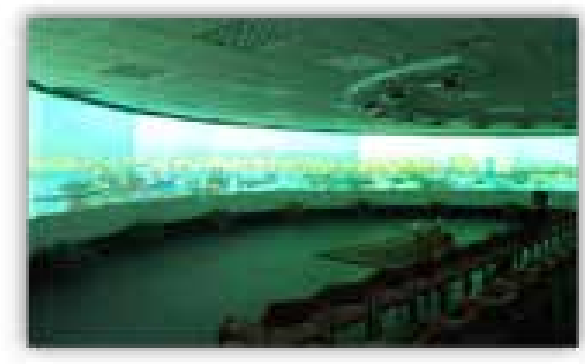

Figure 2: Culturama
"Panorama Heritage", CultNat, accessed May 5, 2016. htpps://wwww.ultnat.org/Culturama.

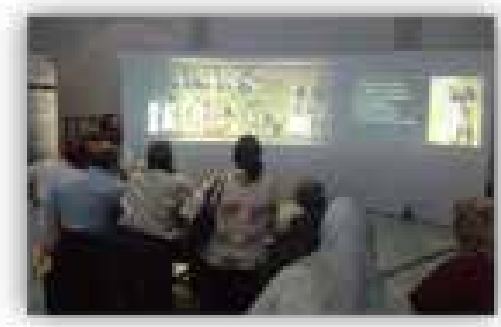

Figure 3: Mini Culturama in the Egyptian Museum, ‘One god and three religions exhibition'

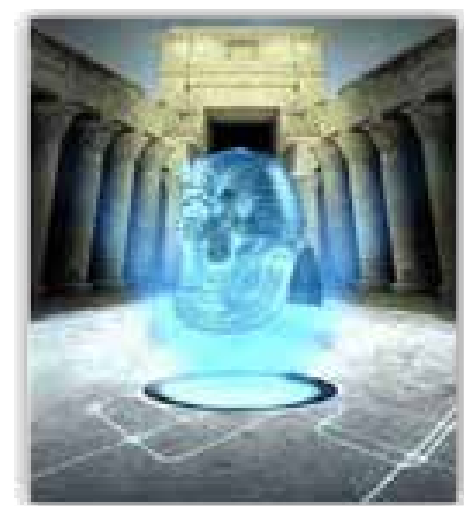

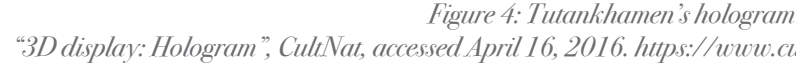

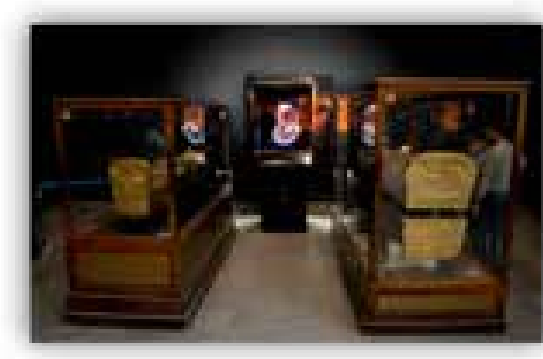

Figure 5: Tutankhamen hologram
Calken by the CultNat safff: Ocober 2015

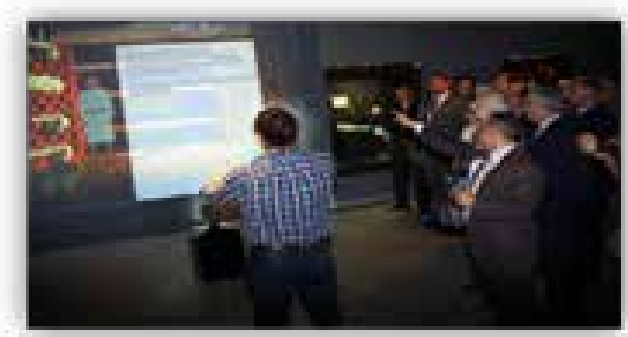

Figure 6: Keys to Rome serious game in BA Antiquities Museum

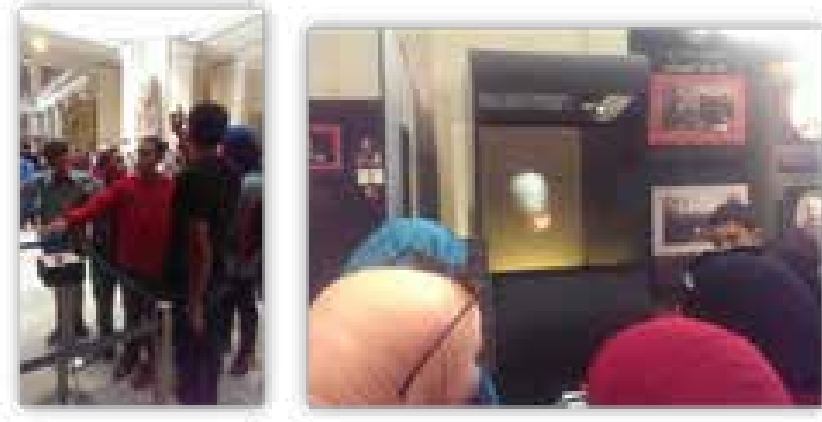

Figure7: The Hologram in Selim Hassan temporary exhibition in the Egyptian Museun 


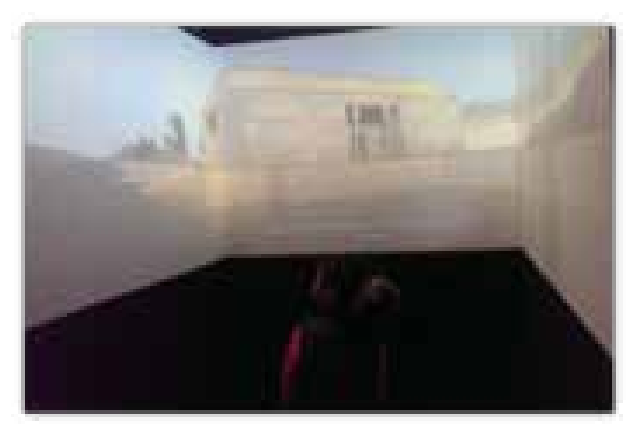

Figure 8: The Cave (the causeway of Unas)
Taken by the author Norember 2016)

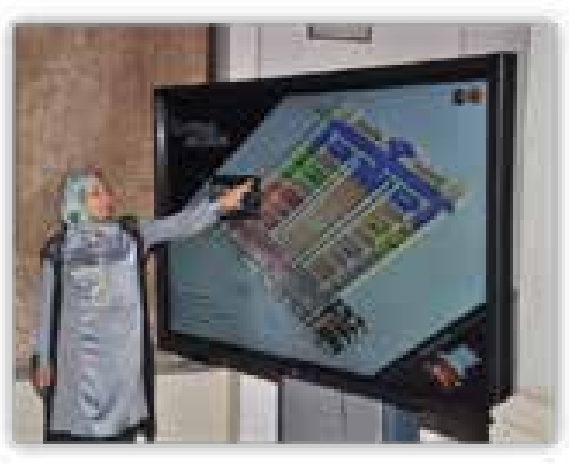

Figure 10: The touch screen, interactive plan of the Egyptian museum

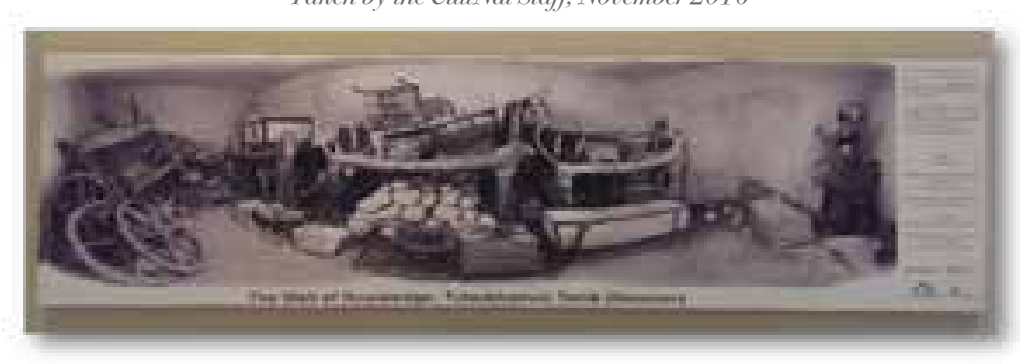

Figure 11: the wall of Knowledge: Tutankhamen tomb discovery

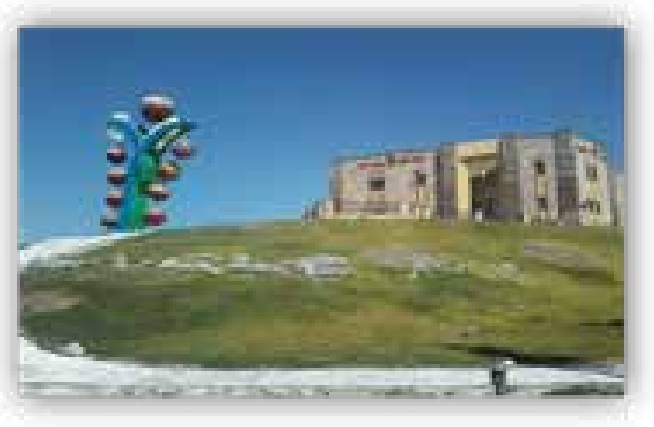
Figure 12: The Nile museum monument
Nile museum, "The Nile museum monument", Facebook, September 7, 2016,
hitps:/ wwow:facebook.com/Nile-museum-1567474330227402

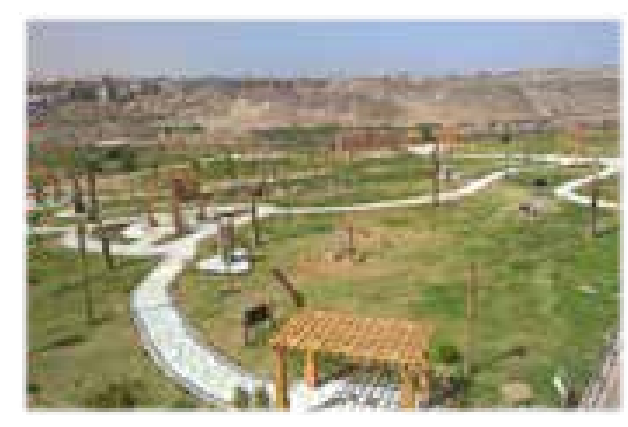

(1) Vile museum, "The Nile musseum surrounded area", Facebook, September 7, 2016

(157517
Figure 14: The Nile muscum visitor evaluation

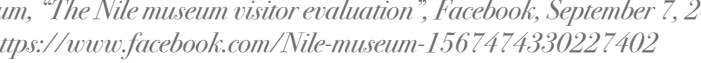

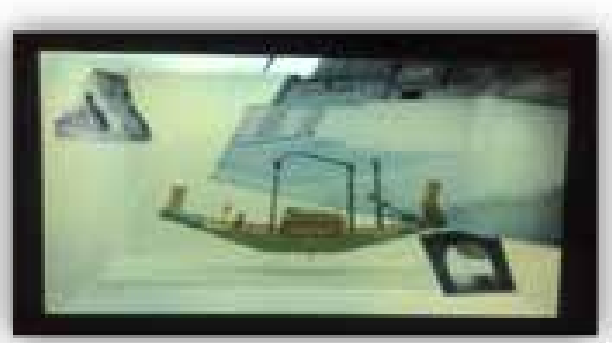

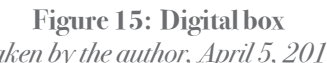

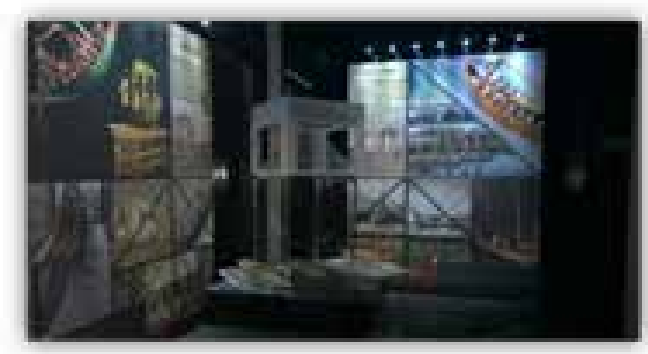

Figure 16: the pyramid Hologram
Taken by the author, April 5, 2016 


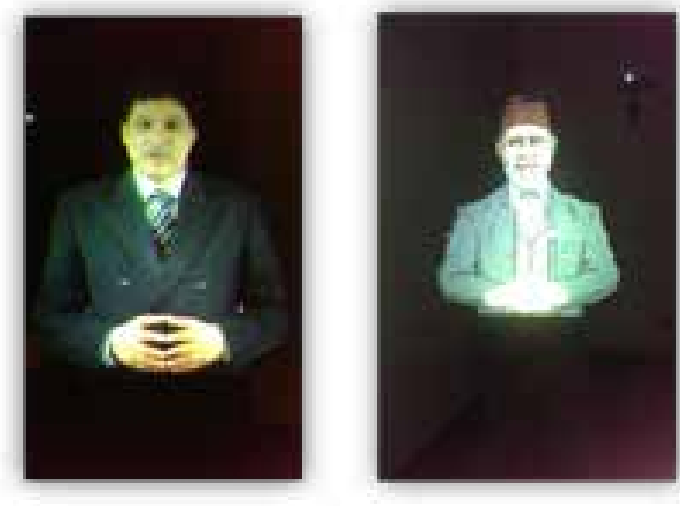

Figure 17: Digital Hologram
Taken by the author:April5, 2016

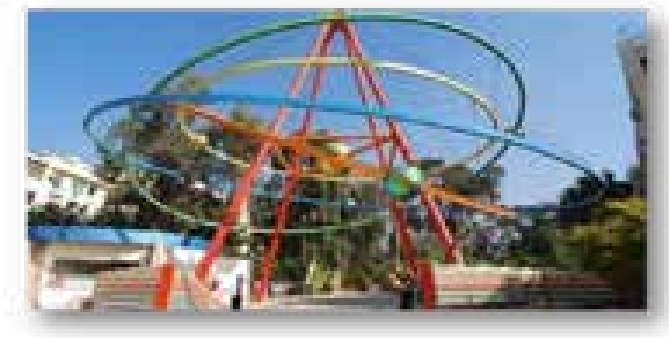

Figure 18: The Children's Civilization and Creativity entrance
Child Musseum, "The Children's Sivilization and Creativity entrance", Facebook, May, 2016, hutps://m.facebook.com/childmuseum.eg;

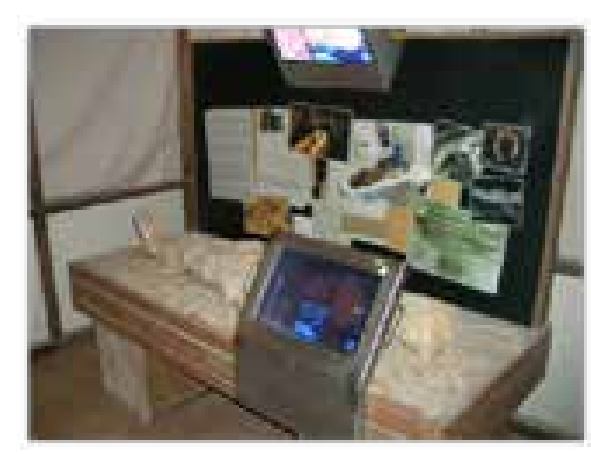

Chid Higure 19: Numm hutps://m.facebook:com/childmuseum.eg/

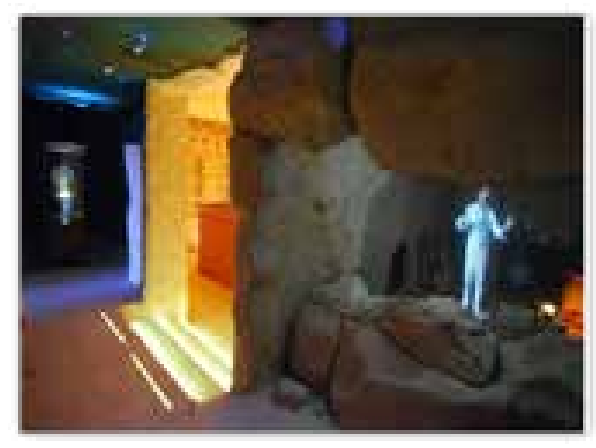

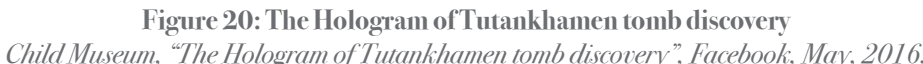
hitps://m.facebook:com/childmuseum.eg

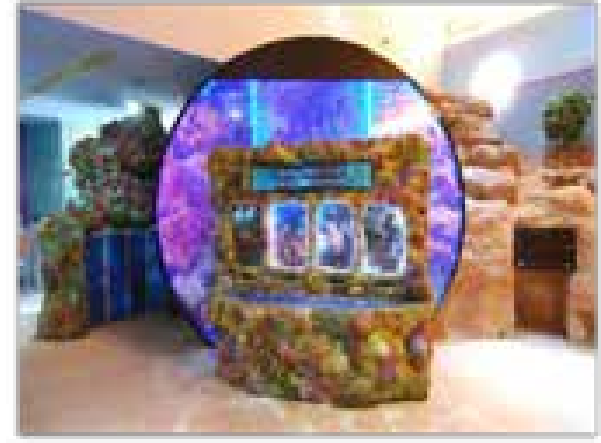

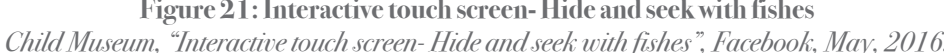
htps://m.faceboook.com/childmuseum.eg 


\section{Bibliography:}

Amin Shreen M. Director of the Children museum in the Egyptian museum. Personal communication with author. August 1, 2016.

Bihler, Pascal, Imhoff, Paul and Cremers, Armin B. "Smart Guide - A Smart Phone Museum Guide with Ultrasound Control". The 8th International Conference on Mobile Web Information Systems (MobiWIS), Procedia Computer Science 5 (2011): 586-592. Ontario, Canada.

CultNat. "Panorama Heritage". Accessed May 5, 2016. https://www.cultnat.org/Culturama.

CultNat. "3D display: Hologram”. Accessed April 16, 2016.https://www.cultnat.org/IT TechnologyDetails?id=15.

Economou, Maria and Pujol- Tost, L. "Evaluating the Impact of New Technologies on Cultural Heritage Visitors”. Technology Strategy, Management and Socio-Economic Impact Heritage Management Series, vol. 2 (2007): 109-121. J. McLoughlin, J. Kaminski and Sodagar, Archaeolingua, Budapest.

Fatma Mostafa. Deputy General Manager of the Children's Civilization and Creativity Center. Personal communication. June $12,2016$.

Hesham Farghaly, personal communication with author, April 23, 2016.

Hussein, Hesham and Mousa, Essam. 'The Effect of Modern Techniques on Developing Museums in Egypt'. Journal of Engineering Sciences. Assiut University, Faculty of Engineering, vol. 41, no. 2 (March 2013): 645 -664. Egypt.

Pescarin, Sofia. "Museum and Virtual Museums in Europe: Reaching Expectations". SCIRES- Sci. Res. Inf. Technol., vol. 4, no. 4 (2014): 131-140. Caspur-Ciber, Rome, Italy.

Salah el-Din, Ahmed. “The Narrator: A Smart Data Offloading System for Interactive Navigation in Museums”. The 10 International Computer Engineering Conference (ICENCO), IEEE (2014): 149-154. Egypt.

Saleh, Fathi, Nabil, Mohamed and Sameer Nessma. "The wall of Knowledge". Augmented Reality (AR) and mobile application project. Developed by the Bibliotheca Alexandrina (2018): 1-33.

Velarde, Giles. Designing Exhibitions, Museums, Heritage, Trade and World Fairs. England and USA: Ashgate, 2001.

Vom Lehn, Drik and Heath, Christian. "Accounting for new technology in museum exhibitions. International Journal of artsmanagement (2005): 11-21. 